\title{
Legende hender
}

Jeg lå på et tremannsrom på Kvinneklinikken på Ullevål og følte meg dårlig. Noen dager før var jeg blitt operert. Utgangspunktet var en rutineoperasjon som ikke hadde gått helt som planlagt. Inngrepet ble mer komplisert og langvarig enn ventet - og kirurgen fant en tumor som måtte undersøkes nærmere. Jeg hadde trodd at jeg som lege var forberedt på hva jeg skulle igjennom og at jeg hadde kontroll over mine egne forventninger og reaksjoner. Det viste seg å være feil. Jeg var sliten og fortvilet, jeg hadde vondt, tarmen fungerte ikke - og jeg var redd. Så gikk døren opp, og en mann kom inn. Han var ganske fåmælt. Han gikk bort til meg, la en hånd på underarmen min (min egen hånd var full av venekanyler). «Det skal gå bra, det her,» sa han og lot hånden hvile noen sekunder ekstra. Plutselig endret situasjonen seg. Plagene virket ikke så uutholdelige - ja, jeg kan godt kalle det et vendepunkt. Det er iallfall slik jeg husker det. Jeg kan faktisk nå, 13 år senere, kjenne varmen og tyngden fra hånden hans når jeg tenker tilbake. Og jeg kan fornemme lettelsen og takknemligheten over at han var der og ville hjelpe. Det ga håp om at jeg ville klare å stable meg på beina.

Var det Snåsamannen som var kommet på besøk? Nei, det var Erik Qvigstad, overlegen som hadde operert meg noen dager tidligere. Var det overnaturlige krefter i sving på Kvinneklinikken? Eller var det rett og slett slik at en god lege var kommet på visitt?

Hva vil det si å være «god lege» i den moderne, til dels høyteknologiske og upersonlige bedriften som helsetjenesten har utviklet seg til? Med den utrolige veksten og endringen i muligheter for diagnose og behandling som har skjedd særlig de siste 50-60 årene, er det nærliggende å tro at det er nødvendig fullstendig å redefinere den rollen leger bør spille. Mange har valgt å gjøre det, og finner det mest meningsfylt å være rådgivere og tolkere av prøvesvar og retningslinjer. Men kanskje har ikke essensen i legerollen forandret seg så mye som samfunnet omkring. Og er det når pasientene fornemmer at denne essensen blir borte, at de søker trøst og tilflukt i den såkalte alternative medisin?

Sir William Osler (1849-1919) er kanskje den som har bidratt mest til å definere «moderne» medisin, selv om det skjedde for hundre år siden. Han levde i en periode da «skolemedisinen» gikk over fra å være basert mest på tro til oppdagelsen av konkrete årsaker til sykdom, f.eks. bakterier. Likevel mente Osler at hans viktigste bidrag til moderne medisin var å insistere på at studentene måtte lære faget gjennom å se og snakke med pasientene. Han var en beundret og skattet kliniker, humanist og lærer. Han var også velkjent for sine utallige kloke formuleringer om leger og legevirksomhet. «The physician needs a clear head and a kind heart,» er en av de mest kjente. Det virker kanskje litt festtalepreget ved første gjennomlesing. Utsagnet er imidlertid bare begynnelsen på en setning som fortsetter slik: «... his work is arduous and complex, requiring the exercise of the very highest faculties of the mind, while constantly appealing to the emotions and finer feelings» (1). Formuleringene er hentet fra forelesninger publisert første gang i 1904.
Osler så at det ikke var noen motsetning mellom omfattende, gjerne høyspesialisert, kompetanse og personlig engasjement $i$ den enkelte pasient. Begge deler trengs for å kunne være lege. Du må naturligvis til enhver tid være oppdatert. Men du blir ikke mindre lege av å ta en pasient $i$ hånden, se ham i øynene og lytte. Det er heller ingen motsetning mellom å være en god lege for enkeltpasienter og engasjert i samfunnet omkring, i medisinens vilkår og i helsepolitikk.

Legerollen er nå under press utenfra, fra en upersonlig stat som styrer med pålegg, penger og statlige retningslinjer $(2,3)$. Mette Brekke \& Per Fugelli formulerte det slik i 2004 (4): «I Norge kommer truslene mot legenes integritet og kliniske frihet fra offentlige myndigheter som Rikstrygdeverket og et Sosial- og helsedirektorat som tidvis minner om et medisinsk politidirektorat. Det legges opp til en form for kommandomedisin hvor legene med påbud, belønning og straff skal presses inn i rigide regimer med mindre og mindre rom for individualisering og klinisk skjønn.» Men legerollen trues også av oss selv, innenfra. Hvis vi ikke tør eller vil være personlige, til stede, ta på, se på, lytte til, gir vi slipp på en vesentlig del av det å være lege (5-7).

Sitatet $\mathrm{i}$ innledningen er siste setning $\mathrm{i}$ en forelesning - «The care of the patient» - som Francis Peabody holdt ved Harvard Medical School. Den ble publisert i JAMA i 1927 (8), men beskriver vesentlige sider ved legerollen også i dag: «The essence of the practice of medicine is that it is an intensely personal matter, and one of the chief differences between private practice and hospital practice is that the latter always tends to become impersonal. At first sight this may not appear to be a very vital point, but it is, as a matter of fact, the crux of the whole situation. The treatment of a disease may be entirely impersonal; the care of a patient must be completely personal.» Leger skal ikke bare kurere lidelse, men påvirke hvordan pasienten ser på sykdommen, på seg selv og på sine utsikter.

\section{Charlotte Haug}

redaktør

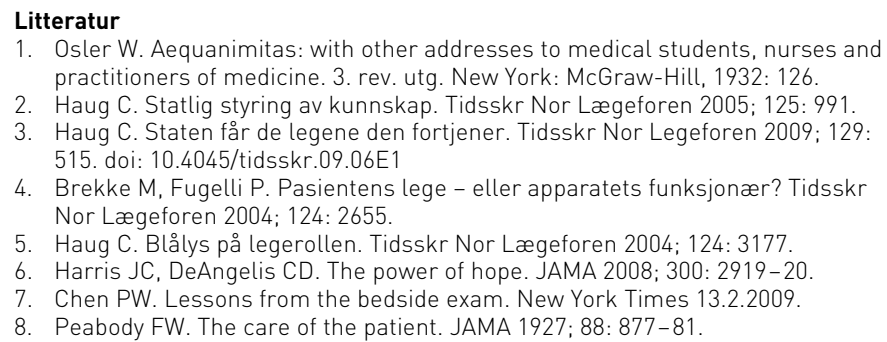

